\title{
Village Community Food Security through Development Plantation and Animal Husbandry Products in Menteng Karya Village, Kapuas Regency
}

\author{
Dhanu Pitoyo \\ Department of Sociology, Faculty of Scientific and Political Sciences, Palangka Raya University, Indonesia \\ dhanu@fisip.upr.ac.id
}

\section{Abstract}

This study aims to analyze that the empowerment of villagers can be obtained from the development of plantation and livestock products to increase self-reliance, there is a creative side to maintain food security for residents of Menteng Karya Village, Kapuas District, Central Kalimantan Province. The data were obtained based on the results of in-depth interviews from October to December 2020 with 5 UKM players and supported by secondary data from relevant sources. The data is processed based on the type of qualitative research. In the results of this study, it is found that SMEs have been able to develop products from their agricultural products, but encounter obstacles in the form of marketing, packaging, and licensing in the form of P-IRT and halal certification of the products they produce.
Keywords

empowerment; creativity, UMM product development; Menteng Karva Villade

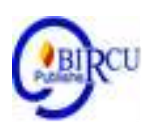

\section{Introduction}

Interpreting development, especially for rural areas, currently the paradigm has changed from building a village to a developing village. A word that has an extraordinary meaning, the word contains an understanding that the village is no longer seen as an underdeveloped, slum, underdeveloped area, but an area that has the potential to be developed both naturally, human resources, products produced to local values. special. In Mustika et al, it is stated that to build food security requires human resources who have knowledge and are facilitated related to the main tasks and functions of food security knowledge (Mustika et al, 2008). The government should provide full support in creating food security, as conveyed byIn his research, to strengthen the defense of food security, a policy of stopping or tightening the conversion of agricultural land, especially rice fields, is needed so that it is not used for infrastructure development. Apart from that it is deep conveyed the results of his research that communication is needed in developing food security institutions in society.

One of the things that can be seen from the real action of the meaning of developing villages is the support of the central government, through cross-ministerial efforts to provide space for the development of village potential, for example through the policy of allocating village funds and other matters related to efforts for rural independence. In other words, whatever village potentials that can be developed will get attention from the government. 
There is an opportunity for the village at this time, so that the autonomy side is increased in order to increase the independence and welfare of the villagers, including in Menteng Karya Village, Dadahup District, Kapuas Regency. Sometimes it can be seen that many villages with all their potentials have not maximized their potential so that instead of their citizens being prosperous and independent, they experience new poverty vulnerabilities. Potential agricultural products in Menteng Karya Village are watermelon, which when the harvest is abundant, then bananas, the result of cassava plants and duck farming, although still on a small scale. However, the analysis shows that all these things have been able to improve the welfare of the villagers.

\section{Review of Literature}

\subsection{Overview of the Sustainable Development Paradigm}

Community empowerment is a process of creating a community with much greater control over its environment. The process demands organisational means in order to develop (Badaruddin et al, 2020). Therefore, the practice of community empowerment here is conceived of as an effort or way by which people, organizations and communities are directed to be able to master their lives (Damsar \& Indrayani, 2016). With this concept, the practice of community empowerment is not only understood as a change activity carried out from within individuals, communities or organizations but also requires support and encouragement from outside parties, especially support from institutions that have a role in empowerment practices. (Saleh and Mujahiddin, 2020)

Community empowerment can be understood in the context that the development paradigm has changed the situation, because community strengthening will have an impact on development that has value. Based on the previous paradigm, which turned out to torment the community with false obedience or a model of exploitation for community members by those who have power with all of its programs which are actually incorrect. This section will describe the development paradigm that provides a way for the community to develop by exploiting its potential, so that development problems such as poverty, underdevelopment and other social problems can be resolved by empowering the community.

Empowerment means providing resources, opportunities, knowledge, and skills to improve the ability of society to determine their own future and to participate and influence the lives of its people (Ife and Tesoriero in Saleh et al, 2019). Understanding empowerment is directed more towards improving the ability of a society to be self-sufficient, can control its future and can even influence others.

The failure of various development theories so far has led to a new theory which has become known as the theory of development which is centered on the people (people centered development). The originator of this theory is David Korten in 1984 in Mardikanto (2010) mentions this theory as one of the answers in finding a just direction of development which presents important new potentials to strengthen human growth and welfare, justice and the sustainability of development itself, then hence the people become the center of studies in development. In another part, this theory states that development must be oriented towards improving the quality of human life, not solely on economic growth through markets or strengthening the State.

In simple terms, Korten (1993) states that production-centered development focuses more on:

1. Industry and not agriculture, even though the majority of the world's population obtain their livelihoods from agriculture; 
2. Urban areas and not rural areas;

3. Centralized ownership of productive assets, and not extensive productive assets;

4. Development investments are more profitable for the group little rather than much;

5. Optimal use of capital and not use of resources optimal human, so that capital resources are utilized while human resources are not used optimally;

6. Utilization of natural resources and the environment to achieve short-term increase in physical wealth without management for sustains and enlarges resource outputs, by giving rise to the destruction of the environment and the natural occupation of the natural resource base fast;

7. Efficiency of large-scale units of production that are interdependent and based on differences in international profits, leaving the diversity and adaptability of small-scale units organized in order to achieve local self-sufficiency, resulting in an energy inefficient economy; lacks adaptability and is prone to serious interference due to damage or political manipulation in a part of the system.

There is a broad side of autonomy for humans (society) to be creative and empowered in fulfilling their life's needs, this simply indicates that whatever is the habit of society in trying and acting must be appreciated instead of imposing programs from above, so it can also be said that whatever the will of the community needs to be supported by the government, because they are the ones who understand and understand the continuity of their lives in their own way. Such a model can also be said to be a bottom-up program, namely the existence of the authority given by the State to the community to manage their lives for the better.

This situation then by Korten (1993) states that the concept of people-centered development views people's creative initiatives as the main development resource and views their material and spiritual well-being as the goals the development process wants to achieve. In another section it is also mentioned that there are three important themes that are considered decisive for the concept of people-centered planning, namely:

1. Emphasis on the support and building of self-help enterprises the poor to take care of their own needs;

2. Awareness that although the modern sector is the main source of conventional economic growth, the traditional sector is the main source of life for the majority of poor households;

3. The need for new institutional capacities in an effort to build the capacities of poor beneficiaries for productive and self-reliant management based on local resources.

In another part, according to Sulistiyani (2017) in Anup Shah (1987) this concept was initiated by the World Commission on Environment and Development, this commission is also called the Brundtland Commission in accordance with the name of its chairman, Mrs. Brundtland, who became the prime minister of Norway. Sustainable development is defined as development that meets the needs of presents without compromising the abilities of future generations to meet their own needs. In other words, sustainable development is an effort to meet the needs of the present generation without sacrificing the needs of future generations. Meanwhile, the Oxford Concise Dictionary of Politics says that sustainable development is a concept that emphasizes the balance between the interests of economic growth and environmental protection. 


\subsection{Menteng Karya Village Data}

As part of this analysis, the condition of Menteng Karya Village can be seen in:

\section{a. Borderline}

Menteng Karya Village borders the following areas:

North: Dadahup Raya Village

East: Kapuas Murung District (Talekung Punei Village)

South: Kapuas Murung District (Manggala Permai Village)

West: Mentangai District (Suka Maju Village)

\section{b. Menteng Karya Village Area Map}

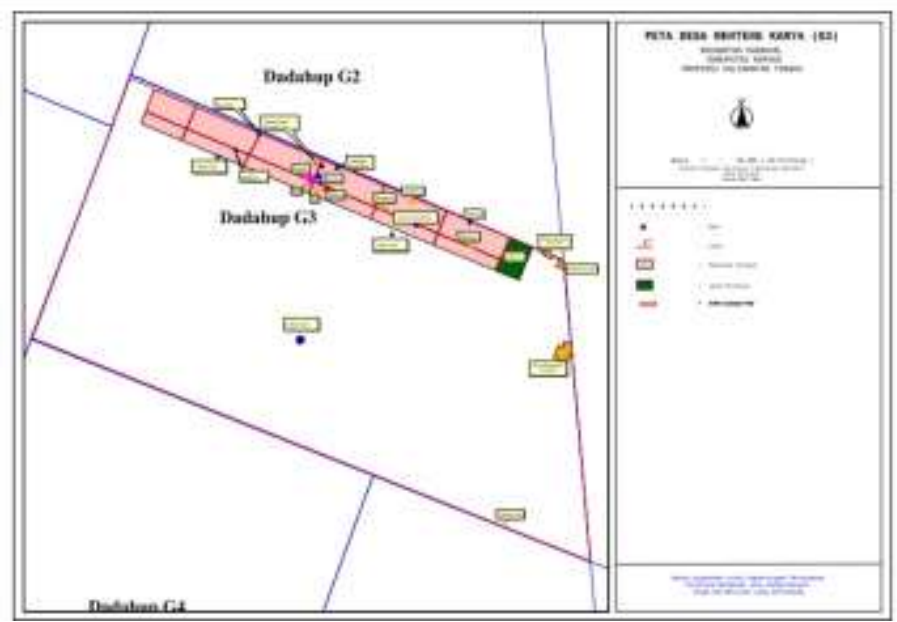

c. Total Population and Community Livelihoods

\begin{tabular}{|l|c|c|c|c|c|c|c|}
\hline No. & Village Name & RW & RT & $\begin{array}{l}\text { Number of } \\
\text { households }\end{array}$ & \multicolumn{2}{|c|}{ Number of Souls } & amount \\
\hline & & & & & L & P & \\
\hline 1 & Menteng Karya Village & 1 & 1 & 27 & 52 & 47 & 99 \\
\hline & & & 2 & 18 & 29 & 26 & 55 \\
\hline & & & 3 & 26 & 43 & 40 & 83 \\
\hline 2 & Menteng Karya Village & 2 & 4 & 25 & 49 & 49 & 98 \\
\hline & & & 5 & 34 & 64 & 48 & 112 \\
\hline & & 6 & 35 & 61 & 62 & 123 \\
\hline & & & & & & 570 \\
\hline
\end{tabular}

Source: Menteng Karya Village Profile Book, 2018

Menteng Karya Village has a total population of 570 people, which is divided into two Rukun Warga (RW) areas, with six Rukun Tetangga (RT) areas like villages in Kalimantan, Menteng Karya village is considered a quiet village because if it compares to villages on the island of Java which is up to thousands of inhabitants. As for the livelihoods of the people of Menteng Karya Village, generally as farmers and employees of oil palm plantation companies. This village is one of the villages that is considered unique because the surrounding area is an oil palm plantation and its inhabitants are the majority of residents from the island of Java or transmigrants. 
There is 1 mosque and 1 church, the residents are very open and friendly and know each other. For the education sector, there are 1 elementary school and 1 junior high school if you want to continue their education to the public high school level, the children in Menteng Karya village will go to the capital of Kapuas district. During this pandemic, Menteng Karya Village was still in an area called the green or safe zone, but schools were closed according to the health protocol set by the government.

The soil conditions are predominantly peat and yellow soil, there are several areas that are suitable for agriculture but are more suitable for plantations, for example bananas, cassava, chilies, vegetables, watermelon and petai. For the development of products from the garden, the residents usually make banana chips, while for other plantation products there is no development of this product, this indicates that the creativity of the villagers is still limited

\subsection{Interpreting Empowerment}

Community empowerment has many dimensions, but the most important thing is the ability of each individual to try to be independent by utilizing the potential around him.

According to Friedman (1992) in Adiwijaya (2020), it provides dimensions in describing empowerment, namely: alternative development: 'inclusive democracy, appropriate economic growth, gender equality and intergenerational equity. " From this opinion, it can be seen that there is an emphasis on the balance between the interests of economic growth and the protection / preservation of nature; sustainability. Furthermore, in the context of community development with all its activities, it is best to avoid the "doing for the community" work method, but adopt the "doing with the community" work method.

In this understanding, it can be seen that the doing for work method will make people passive, less creative and helpless, and even educate people to depend on government assistance or voluntary organizations that provide assistance. On the other hand, the doing with work method stimulates the community to be active and dynamic and is able to identify which needs are real needs, felt needs and expected needs.

This is what can then be called a form of development that comes from citizen initiatives as part of an effort to escape from the trap of poverty and underdevelopment. By Noor (2011) provides three aspects of community empowerment:

1. Creating an atmosphere that allows the community's potential to develop (enabling)

2. Strengthening the potential of the community (empowering)

3. Protecting and defending the interests of the lower people (protecting)

There is the widest possible open access for people who want to develop themselves and their communities in maximizing the resources they have. The use of these resources should be supported, not hampered by those who have power. This condition by Mardikanto (2010) states that empowerment can be understood as an effort to meet the desired needs, both individuals, groups and communities in order to make choices and control the environment in order to meet needs such as access to existing resources.

Furthermore, improving the quality of life and welfare of the community becomes a reference in seeing other dimensions of empowerment, this can be seen in terms of:

1. There is economic improvement in the development of food sufficiency

2. Social welfare and education and health

3. Guaranteed independence

4. Guaranteed security

5. Free from greed and guaranteed HAM 


\section{Research Methods}

To get results in accordance with the theme of this study used methods that are guided by qualitative research methods. According to Bogdan and Taylor in Moleong (2004) qualitative research methods are research that produces descriptive data in the form of written or spoken words from people whose behavior is observed. The rule used in this type of qualitative research is descriptive qualitative with the aim of providing an assessment or analysis of the symptoms, an or many events that occur in accordance with the focus of the study.

The data obtained were based on observations, interviews and documentation in accordance with the study which became the research theme, namely on the Empowerment of Village Residents through the Development of Agricultural Products in Menteng Karya Village, Kapuas Regency, Central Kalimantan Province. For data analysis based on interactive techniques from Miles and Huberman in Sugiyono (2008) that activities in qualitative data analysis are carried out interactively and continue to completion, so that the data is saturated. Activities in data analysis, namely data reduction, display data, and conclusion drawing / verification.

\section{Results and Discussion}

In this discussion, based on the results of data reduction from 5 (five) key informants who were interviewed regarding the product developers of their agricultural products, there are 2 (two) banana chip craftsmen, 2 (two) cassava chip craftsmen, and 1 (one) egg craftsman. Salty, can be explained from the following aspects:

a. Village land conditions

Menteng Karya Village is a fertile area so that the results of plantations developed by the community include watermelon, cassava, chilies, petai, and bananas if the yields are abundant. As for duck breeders, because in this area a lot of water flows are intentionally made to irrigate oil palm plantations (handil) so that it is very supportive of the development of duck farms. In addition, during this pandemic, because this area is included in the green zone (safe) category, the activities of residents for gardening are not a problem.

\section{b. Plantation product development}

Only bananas and cassava can be developed by the villagers from the villagers' gardens, while watermelons, bananas, and chilies are sold directly. While bananas and cassava is made into chips with three flavors, namely original, sweet, and spicy.

\section{c. Product marketing}

The resulting products are sold by entrusting them directly to the Palingkau area, Kapuas Murung District. In this area it is fairly crowded because in this area there is a boarding school which is quite famous for the Kapuas district where many students come from all areas in the Kapuas district. From this it can be seen that the education sector provides a change and can become an attraction in marketing products. There is also a marketing model that is carried out by bringing products to Banjarmasin because one of his son's product makers is currently undergoing studies in that city. 


\section{d. Some Downsides}

Weaknesses that can be seen from the development of existing products are firstly, the packaging is still simple, the existing packaging only relies on the same plastic as sugar plastic. Second, the brand (brand) is made very simple even with standard print quality. Third, marketing that has not been able to reach other areas is still limited to the interdistrict level. If you rely on exhibitions, you cannot afford to leave Menteng Karya Village, but only a very small scale of production can be sold. Fourth, there has been no intensive coaching from the agencies related to product development results. Fifth, the road access to Menteng Karya Village is still not asphalted, so the journey feels far from the capital of Central Kalimantan Province or even the capital of Kapuas Regency.

In the above conditions, it can be seen that in Menteng Karya Village, even though the raw materials are abundant, there are still many obstacles that are faced, so to increase competitiveness as a business that can have an effect on a community is still not successful, on the other hand there is a mindset that is built by actors business in the village is limited to developing products from abundant yields only as a hobby, because their main job is actually farmers whose produce from raw materials is considered capable of fulfilling their daily lives.

However, this creativity is not only interpreted in a simple way, this is an initial movement in empowering the community, in the future there will definitely be seen the results of the products developed. Menteng Karya Village has a strategic position in the development of inland fisheries and chicken or duck farming because the surrounding villages are included in the national food estate project, so it is possible to support the project.

The reality of the conditions in the villages in Central Kalimantan is generally the same, an abundance of raw materials but minimal product development, but when there are products that are developed from an abundance of agricultural products, they are constrained in packaging and marketing so that they seem to have no competitiveness.

It is the duty of all parties to provide a stimulus in the development of products originating from the village and must have distinctive characteristics so that the product developed becomes an icon that can make an area known to the wider community, then it is also necessary to pay attention to online marketing either by utilizing existing social media or market places.

\section{Conclusion}

Food security has been carried out by residents of Menteng Karya Village, Dadahup Subdistrict, Kapuas Regency through product development in utilizing abundant plantation and livestock products by making banana chips, cassava chips and salted eggs. However, the creativity of these residents did not run optimally due to various obstacles, but from the aspect of empowerment it can be considered that it has been running as a forerunner to community independence for the future. 


\section{References}

Adiwijaya, Saputra. (2020). Kreatif di Masa Pandemi - Bahan Webinar Menyambut Tatanan Kehidupan Baru Kesempatan dan Tantangan Pemberdayaan Masyarakat 10 Agustus 2020 kerjasama FK UPR (AMSA)-Himsos UPR dan Ibu Ary Egahni Anggota Komisi III DPR RI.

Buku Profil Desa Menteng Karya, tahun 2018

Koesoemowardani, N., \& Sumardjo, S. (2008). Peran Komunikasi dalam Pengembangan Kelembagaan Ketahanan Pangan Masyarakat; Kasus Lumbung Pangan di Ciamis, Jawa Barat. Jurnal Komunikasi Pembangunan, 6(2), 246220. https://doi.org/10.29244/jurnalkmp.6.2.\%p

Korten, D.C. (1993). Menuju Abad ke-21: Tindakan Sukarela dan Agenda Global Forum Pembangunan Berpusat-Rakyat. Jakarta: Yayasan Obor Indonesia dan Pustaka Sinar Harapan.

Mahbubi, A. (2013). Model Dinamis Supply Chain Beras Berkelanjutan. Jurnal Manajemen Dan Agribisnis, 10(2), 81-89.

Mardikanto, Totok. (2010). Model - Model Pemberdayaan Masyarakat. UNS Press. Surakarta.

Moleong, Lexy J. (2007). Metodologi Penelitian Kualitatif, Penerbit PT Remaja Rosdakarya. Offset. Bandung.

Mustika, S., Setiawan, B., \& Briawan, D. (2008). Keragaan Penyuluh Pertanian Dalam Upaya Mendukung Pembangunan Ketahanan Pangan Di Kabupaten Lampung Barat. Jurnal Gizi Dan Pangan, 3(3), 185. https://doi.org/10.25182/jgp.2008.3.3.185-191

Noor, Munawan. (2011). Pemberdayaan Masyarakat. Jurnal CIVIS. Vol 1, No 2 (2011)

Saleh, A. et al. (2019). Development of Banking CSR Model for Community Empowerment Slum Area in Medan City. Budapest International Research and Critics Institute-Journal (BIRCI-Journal). P. 39-50.

Saleh, A and Mujahiddin. (2020). Challenges and Opportunities for Community Empowerment Practices in Indonesia during the Covid-19 Pandemic through Strengthening the Role of Higher Education. Budapest International Research and Critics Institute-Journal (BIRCI-Journal). P. 1105-1113.

Sulistyani, Ambar Teguh. (2017). Kemitraan dan Model-Model Pemberdayaan (Edisi 2). Gava Media. Yogyakarta.

Sugiyono. (2008). Metode Penelitian Kunatitatif Kualitatif dan R\&D. Alfabeta. Bandung. 